\title{
DISCURSO ORGANIZACIONAL: UMA PESQUISA A SER EMPREENDIDA ENTRE AS ÁREAS DE COMUNICAÇÃO E ADMINISTRAÇÃO
}

\section{ORGANIZATIONAL DISCOURSE: A RESEARCH IN COMMUNICATION AND MANAGEMENT AREAS}

\author{
Marta Cardoso de Andrade ${ }^{1}$
}

\begin{abstract}
RESUMO
Este artigo apresenta uma reflexão sobre a pesquisa interdisciplinar entre as áreas da Administração e a da Comunicação com foco na construção do discurso organizacional. Os estudos centrados nesse tipo de discurso são importantes para garantir a unidade comunicacional nas/das organizações, bem como auxiliar na construção de uma imagem empresarial positiva e coesa. O objetivo deste trabalho é entender como se empreende uma pesquisa centrada na compreensão de como esse discurso é construído e como ele auxilia na produção de uma imagem corporativa favorável. Para tanto, analisa-se uma peça publicitária do Banco do Brasil, utilizando a teoria da Comunicação Organizacional e a Análise do Discurso, linha francesa, a qual disseca o discurso com base nos elementos linguísticos e no co-texto que o compõe. Ambos são igualmente responsáveis pela construção de uma imagem atrelada aos valores praticados no próprio Banco e, consequentemente, que o favoreça mercadologicamente.
\end{abstract}

Palavras-chave: Comunicação. Administração. Imagem organizacional. Identidade organizacional. Pesquisa.

\begin{abstract}
This article presents a reflection on interdisciplinary research in the fields of Management and Communication focusing on building organizational discourse. The studies focused on this type of discourse are important to ensure the communication unit in organizations, as well as assist the building of a positive corporate image. The objective of this work is to understand how to carry out research focused on understanding how this discourse is constructed and how it assists in the production of a favorable corporate image. To this end, an advertisement of the Bank of Brazil is analyzed using the theory of Organizational Communication and the French School of Discourse Analysis, which analyzes the discourse based on the linguistic elements and co-text that compose it. Both are responsible for the construction of an image linked to the values practiced within the Bank and, as a consequence an image which favors it in terms of market.
\end{abstract}

Keywords: Communication. Management. Organizational image. Organizational identity. Research.

${ }^{1}$ Doutora e Mestre em Letras pela Universidade Federal da Bahia, pesquisa na área de Discurso Organizacional; Bacharel em Comunicação Social com habilitação em Relações Públicas pela Universidade Salvador. E-mail: marta.andrade@unifacs.br 


\section{Considerações iniciais}

Fragmentar o conhecimento para especializá-lo ou unir disciplinas/áreas para abarcar melhor um objeto de estudo? Este artigo não se debruçará nessas questões geradoras de grandes discussões, apenas seguirá/defenderá o segundo posicionamento, tanto no ambiente educacional como no da pesquisa. Assim, seguindo essa mesma linha de pensamento, encontram-se Siqueira e Pereira ${ }^{2}$, afirmando que

A necessidade de romper com a tendência fragmentadora e desarticulada do processo do conhecimento,[sic] justifica-se pela compreensão da importância da interação e transformação recíprocas entre as diferentes áreas do saber. Essa compreensão crítica colabora para a superação da divisão do pensamento e do conhecimento, que vem colocando a pesquisa e o ensino como processo reprodutor de um saber parcelado que consequentemente muito tem refletido na profissionalização, nas relações de trabalho, no fortalecimento da predominância reprodutivista e na desvinculação do conhecimento do projeto global de sociedade.

É sabido que o século XX foi marcado pela predominância da divisão do trabalho intelectual, pela fragmentação do conhecimento e pela excessiva predominância das especializações. Com a virada de milênio, entretanto, presenciou-se a demanda por uma retomada do antigo conceito de interdisciplinaridade que, durante esse século, ficou sufocada pela racionalidade imposta pela Revolução Industrial.

Japiassu (2006) pontuou que o conhecimento e a ação, longe de se excluírem, se conjugam, porque é o homem em situação - e não o homem atemporal, ahistórico, desenraizado culturalmente - quem introduz e instaura o interdisciplinar, cujo caráter exige uma coordenação bem maior de esforços, múltipla pela pluralidade de seus objetos e pela diversidade de seus métodos. Esse mesmo teórico ainda advoga que a ciência é, pelo menos teoricamente, una pelo sujeito que a concebe e a produz, mas díspare em posicionamento frente aos seus objetos de estudo.

Por isso, para fazer e pensar uma pesquisa que se debruçará sobre as especificidade de um objeto/ fenômeno, abarcando-o de forma plural e ampla,

\footnotetext{
${ }^{2}$ SIQUEIRA, Holgonsi Soares Gonçalves; PEREIRA, Maria Arleth. A interdisciplinaridade como superação da fragmentação. Disponível em: $<$ http:// www.angelfire.com/sk/holgonsi/interdiscip3.html>. Acesso em: 21 fev. 2013.
}

deve-se usar o princípio da interdisciplinaridade, em que se dispõe de o que há de mais apropriado para se entender o assunto/tema em cada teoria disponível, as quais já dispuseram premissas para fenômenos similares.

Dessa forma, este documento versa acerca dos entrelaces possíveis entres campos de saberes que se complementam tanto teoricamente como no labutar no mercado profissional, que são a Administração e a Comunicação, mais especificamente na junção dessas duas na Comunicação Organizacional com o auxílio da Análise do Discurso, linha francesa, visando o entendimento da construção do discurso empresarial, cuja contribuição principal desembocará na percepção de uma imagem corporativa favorável.

Dessa forma, o objetivo deste trabalho é entender como se empreende uma pesquisa centrada na compreensão da maneira como esse discurso é construído e como o mesmo auxilia na produção de uma imagem corporativa favorável.

Para tanto, investigar-se-á uma peça publicitária de uma corporação brasileira, o Banco do Brasil (BB), e utiliza-se-á da teoria da Análise do Discurso, linha francesa, a qual disseca o discurso com base nos elementos linguísticos que o compõe e dos elementos constituintes do co-texto ${ }^{3}$, ambos igualmente responsáveis pela construção de uma imagem atrelada aos valores praticados no próprio Banco e, consequentemente, que o favoreça mercadologicamente.

\section{Conceitos basilares}

Interlaces de conhecimento entre áreas que podem auxiliar uma a outra com a produção de conhecimento individual é algo que se presencia cada vez mais hodiernamente, como já se pôde mencionar. Com a Comunicação e a Administração, não foi diferente. Ao contrário, o enlace foi tão produtivo que originou um campo bem específico, intitulado de Comunicação Organizacional, expressão essa usada academicamente, ou Comunicação Empresarial, como o mercado prefere.

Bueno (2009, p. 2) já chamava atenção para a denominação dada para esse nicho da Comunicação, problematizando a questão do uso de terminologias

\footnotetext{
Co-texto são os elementos não-verbais que compõem uma produção, a saber: fotos, gráficos, mapas, entre outros.
} 
díspares para a área, as quais perpassam por Comunicação Organizacional (CO), utilizado pela academia; Comunicação Empresarial, como o ambiente profissional/mercado prefere; Comunicação Corporativa, variação das duas anteriores; Comunicação Institucional, a qual pode gerar uma leitura equivocada $^{4}$, uma vez que não abarca a Mercadológica, que está centrada no diálogo estabelecido com o mercado; e, por fim, a Comunicação Integrada, que será mais depurada no decorrer deste artigo.

Mas, antes de qualquer ponderação, cabe entender e delimentar o que vem a ser cada um desses campos do saber: o da Administração, o da Comunicação e o da sua subdivisão voltada para as organizações.

Marcondes Filho (2009, p. 68) assevera que, etimologicamente, o vocábulo Comunicação origina-se, na língua latina, da palavra communicatio, a qual poderia ser entendida como "estabelecer uma relação com”. Rabaça e Barbosa (2001, p. 157), por sua vez, apontam para um conceito etimológico mais amplo, afirmando que

[....] a origem da palavra Comunicação introduz a idéia [sic] de comunhão, comunidade. Como diz Wilbur Schramm, quando nos comunicamos, tratamos de estabelecer uma comunidade, isto é, tratamos de compartilhar informações, idéias [sic], atitudes. Sérgio Luiz Velozo endossa ao afirmar que Comunicação é fazer participar, é trazer para a comunidade o que dela estava isolado. Comunicar significa, assim, estabelecer comunhão, participar da comunidade, através do intercâmbio de informações.

Sobre a Administração, Lacombe (2009, p. 15) apresenta três definições que cobrem a área e que acabam sendo complementares entre si, são elas:

1 Conjunto de esforços que tem por objetivo: (a) planejar; (b) organizar; (c) dirigir ou liderar; (d) coordenar; e (e) controlar as atividades de um grupode indivíduos que se associam para atingir um resultado comum.
2 Conjunto de princípios, normas, decisões eações visando a aproveitar da melhor forma as circunstâncias externas, de modo a utilizar o mais eficientemente possível os recursos de que dispõe a organização ${ }^{[5]}$ (pessoas, máquinas, informação, [sic]e capital), para fazê-la sobreviver e progredir.

3 Conjunto de esforços e ações de planejamento, organização, liderança, coordenação e controle das atividadesde uma unidade organizacional, área, empresa ou grupo de empresas, diagnosticando suas deficiências e identificando seus aspectos positivos; estabelecendo metas, planos e programas para sanar as deficiências e expandir e desenvolver os aspectos positivos; tomando, dentro do seu âmbito, as decisões e providências necessárias para transformar em realidade esses planos e programas e controlar seus resultados, visando ao cumprimento das metas estabelecidas.

Conclui-se, com base nessas definições, que não existe realização de uma administração sem o componente comunicação, ou melhor, esta é a base de concretização daquela, uma vez que as entradas e as saídas de informação são feitas por via comunicacional. Tavares (2007, p. 13), inclusive, garante e ratifica esse ponto de vista ao advogar que "[...] a comunicação é a base da existência de todas as organizações."

Feito isso, cabe entender o que seria a Comunicação Organizacional. Para Tavares (2007, p. 11), “[...] é a comunicação existente entre a 'organização' (empresas privadas, empresas públicas, instituições, [sic] etc.) e os seus públicos de interesse". Essa seria operacionalizada seguindo "[...] mais ou menos o seguinte: o público interno fica sabendo de ações institucionais e de marketing; os clientes ficam sabendo de ações internas e institucionais; e a sociedade em geral fica sabendo de ações internas, institucionais e de marketing da organização" (p. 13).

Comugando do mesmo ponto de vista, Frank Conrado (apud RABAÇA; BARBOSA, 2001, p. 176-177) termina por observar

\footnotetext{
${ }^{5} \mathrm{~A}$ pesquisadora sabe que há diferença teórica entre o uso dos termos 'empresa', 'organização', 'instituição', 'companhia' e 'corporação'. Porém, para efeitos deste trabalho, esses serão utilizados como sinônimos. Cabe, ainda, um esclarecimento acerca do conceito de Organização, adotado neste artigo e que aparecerá demasiadamente em várias ocasiões neste documento, definido por aquilo que "abrange qualquer tipo de empresa" (TAVARES, 2007, p. 13).
}

\footnotetext{
${ }^{4}$ Na visão de Rabaça e Barbosa (2001, p. 176), a Comunicação institucional é um "Conjunto de procedimentos destinados a difundir informações de interesse público sobre as políticas, práticas e objetivos de uma instituição, interna e externamente, de modo a tornar compreensíveis e aceitáveis essas proposições". Portanto, torna-se uma possibilidade de uso da Comunicação dentro de uma organização, mas que não pode ser confundida com as demais área mencionadas, uma vez que possui um significado bem distante das demais.
} 
[...] que uma organização comunica-se de forma perfeita quando empregados se comunicam de maneira contínua e informal com os escalões superiores, inferiores e de mesmo nível da organização; e quando os empregados e gerentes contam a mesma história da empresa para os clientes, acionistas, governo, comunidades e outros públicos. Através dos centros de comunicação nas organizações, as informações fluem por vários meios. A coordenação das atividade de comunicação organizacional é um meio de visualizar esse processo aberto de troca de informações e uma forma eficiente de fazer a comunicação fluir.

Já Pimenta (2002, p. 99) apresenta uma definição que perpassa por outra visão. Essa advoga que a $\mathrm{CO}$

[...] caracteriza-se, atualmente, como o somatório de todas as atividades de comunicação da empresa. É uma atividade multidisciplinar que envolve métodos e técnicas de Relações Públicas, Jornalismo, Assessoria de Imprensa, Lobby, Design, Marketing, Propaganda, Promoções, Merchandising e Pesquisa.

Sabe-se que essa multidisciplinaridade é muito enriquecedora para constituição de um trabalho de Comunicação, abrindo possibilidades de pesquisas que se debruçam sobre a junção dessas áreas, ou de algumas delas, enriquecendo a visualização do objeto de estudo, uma vez que esse será entendido por meio de variadas expertises.

Seguindo a mesma linha de Pimenta e acrescentando, ainda, a ideia de comunicação como estratégia defendida por Bueno (2009), Marcondes Filho (2009, p. 68) afirma que a CO é uma

Especialidade técnica de apoio estratégico à adminitração das organizações públicas, privadas e sem fins lucrativos, estruturada e conduzida preferencialmente de forma integrada (Margarida Kunsch) e dedicada a tratar das dimensões mercadológica, institucional, administrativa e interna.

Pode-se também observar a CO com base em classificações. A de Restrepo e Ângulo (apud MARCONDES FILHO, 2009, p. 69), por exemplo, a ordena

[...] em quatro dimensões: a primeira seria a da informação (que daria forma ao sistema), baseada nas operações próprias de cada organização e no sistema normativo, entre outros elementos constitutivos. A segunda seria a da divulgação, na acepção de tornar público. A terceira dimensão é a cultural, no sentido de processos socializadores e legitimadores, como ritos e rituais. A útima dimensão é a da participação, onde se reforçam os vínculos, os compromissos, mediante o reconhecimento do outro, num processo marcado pela empresa (Intervir em la organización).

Observa-se, assim, que toda a comunicação circulante nas organizações servem para, além de dinamizar o fluxo processual, fornecer uma "cara" identificatória da própria corporação/empresa.

Já Goodal Jr. e Eisenberg (apud MARCONDES FILHO, 2009, p. 69), visando o aspecto teórico relacionado à questão das classificações,

apresentam-nos cinco visões que têm orientado a observação [desses estudiosos]: a comunicação organizacional como transferência de informação; como processo transacional, como estratégia de controle; como equilíbrio entre criatividade e constrangimento/coação/sujeição; e como espaço de diálogo, em que haveria equilíbrio expressivo entre todos os interlocutores (Comunicação organizacional, equilíbrio, criatividade e coação).

Equilíbrio este que só existe quando os públicos empresariais, ou stakeholders ${ }^{6}$, termo preferido na atualidade, estão, de certa forma, sinergicamente ligados a essa organização.

Marcondes Filho (2009, p. 68) defende que

Hoje, nos meios acadêmicos, admite-se que as organizações são redes de comunicação, marcadas por conversações que condicionam as possibilidades de desempenho, o nível de efetividade, a viabilidade, o êxito ou o fracasso. Nessa visão, a comunicação não se resume a uma atividade operacional e instrumental, mas permeia a vida organizacional, viabilizando, com isso, a construção da cultura e da identidade. O processo comunicativo permitiria uma visão construtivista da realidade organizacional, a partir das múltiplas interações mediadas

\footnotetext{
${ }^{6}$ Stakeholder é um termo que se refere às partes interessadas ou aos intervenientes que devem estar de acordo com as práticas executadas pela empresa. O sucesso de qualquer empreendimento depende da participação dessas partes e, por isso, é necessário assegurar que suas expectativas e necessidades sejam conhecidas e consideradas pelos gestores. De modo geral, essas expectativas envolvem satisfação de necessidades, compensação financeira e comportamento ético. Cada interveniente, ou grupo, representa um determinado tipo de interesse no processo. $\mathrm{O}$ envolvimento de todos os intervenientes não maximiza obrigatoriamente o processo, mas permite achar um equilíbrio de forças e minimizar riscos e impactos negativos na sua execução.
} 
pelas ações histórica, social e política. Assim, a comunicação moldaria a organização. (MARCONDES FILHO, 2009, p. 68-69).

Com base nesse posicionamento, abre-se mais um campo para pesquisa, que é aquele que se debruça sobre a construção da identidade e da imagem organizacional. Este é um assunto com o qual alguns pesquisadores estão trabalhando há bastante tempo, a autora deste artigo inclusive realiza pesquisas em organizações como Banco do Brasil, Odebrecht e Petrobras.

Dada a importância deste tipo de pesquisa, pergunta-se: o que vêm a ser esses dois conceitos fundamentais - identidade e imagem - para as organizações na atualidade?

Para Van Riel (apud ALMEIDA 2009, p. 217), a identidade corporativa "[...] é a coleção de atributos vistos como específicos [...]" da organização; e, segundo a visão de Hannebohn e Blöcher (apud ALMEIDA 2009, p.219), esta “[...] é a estratégia que ajuda a desenvolver a performace econômica e a eficácia da organização. Busca coordenar valores e informações e integrar um senso de cooperação".

Lux (1986) defende que a identidade corporativa é a expressão da personalidade da organização, a qual pode ser experimentada por qualquer um. Isso é manifestado no comportamento e na comunicaçãoda organização e pode ser mensurado como resultado percebido entre grupos internos e externos. (ALMEIDA 2009, p. 218).

Visto o que seria a primeira expressão, deve-se compreender, então, a segunda. A imagem corporativa, segundo Spector (apud ALMEIDA 2009, p. 227) seria "A soma total das percepções das características de personalidade da organização [...]". Para Bevis (apud ALMEIDA 2009, p. 227), “[...] é o resultado em rede da interação do todo de experiências, crenças, sentimentos e conhecimentos que as pessoas possuem acerca da organização". Ana Luísa Almeida (p. 228), por sua vez, defende que esta

[...] refere-se a uma impressão vivida e holística de uma organização, sustentada por determinado segmento de público; parte, resultado de um processo de construção de sentido, desenvolvido por esse determinado público, outra parte, consequência do processo de comunicação da organização, formal ou informal, com maior ou menor controle, siste- matizado ou não, constante ou esporático, bem ou mal gerenciado. Dessa forma, pode-se supor que a imagem é um fator inacabado, por ser receptivo e mutante, sempre passível de modificações e adição de novas informações, podendo alterar ou não o seu significado simbólico, dependendo do modo e constância em que são emitidas novas informações e como essas são recebidas e percebidas.

Mais adiante, Almeida (2009, p. 228) afirma algo que é de fundamental importância para o entendimento deste conceito:

Podemos afirmar que há um esforço por parte das organizações em criar uma impressão pública que atraia o público de seu interesse, ou seja, há uma intencionalidade implícita na imagem organizacional, a qual determina seu gerenciamento. Em outras palavras, a organização, como ator social, pode influenciar deliberadamente, isto é, ela pode ser objeto de uma ação instrumental.

Dessa forma, chega-se ao ponto alto defendido neste artigo, que é justamente a defesa da premissa de que tanto a identidade quanto a imagem corporativa pode ser construída ou comunicada via discurso, formado intencionalmente.

O conceito de discurso adentra a Comunicação como área de conhecimento teórico, via Análise do Discurso (AD), de linha francesa, com a qual, em conjunto com as duas outras áreas já mencionadas (Administração e Comunicação), se institui igualmente uma interfase/união de arcabouço teórico para melhor compreensão daqueles dois fenômenos (identidade e imagem corporativas) que ocorrem com/na organização.

Para efeito de demarcação da gênese da teoria, pode-se, então, afirmar que a AD

[...] é a herdeira das três regiões de conhecimento - Psicanálise, Lingüística [sic], Marxismo - não o é de modo servil e trabalha uma noção - a de discurso - que não se reduz ao objeto da Lingüística [sic], nem se deixa absorver pela Teoria Marxista e tampouco corresponde ao que teoriza a Psicanálise. Interroga a Lingüística [sic] pela historicidade que ela deixa de lado, questiona o Materialismo perguntando pelo simbólico e se demarca da Psicanálise pelo modo como, considerando a historicidade, trabalha a ideologia como materialmente relacionada ao inconsciente sem ser absorvida por ele. (ORLANDI, 2002, p. 20). 
Deve-se, portanto, determinar o que se entende por discurso empresarial (DE) e a importância da sua construção consciente para a organização. Para Tereza Halliday (2009, p. 32), esse tipo de discurso seria “[...] o conjunto de práticas linguísticas, semânticas e retóricas das pessoas jurídicas". Essa mesma teórica estabelece

[...] a comunicação organizacional como construção simbólica da realidade [...] Salienta também que as organizações usam palavras e outros símbolos para informar, apresentar razões e justificar-se, construindo um discurso legitimizante, sintonizado com os interesses e valores de seus públicos. Nesta abordagem [...], o discurso organizacional é tratado como ação e como recurso, tão importante quanto os econômicos, tecnológicos e humanos. Além disso, ele agrega valor na medida em que contribui para aumentar o poder da organização entre seus interlocutores. (HALLIDAY, 2009, p. 31).

Halliday (2009, p. 32), ainda, destaca: “[...] os textos produzidos pelas organizações - difundidos seja por meio de fala, seja por escrito - são a manifestação primordial de seu discurso e a unidade discursiva preferida pelos analistas", uma vez que é por meio desse que os stakeholders formam a imagem da empresa com a qual acaba estabelecendo relacionamentos duradouros ou não.

Entender um discurso é "explicitar e interpretar ao mesmo tempo a relação entre as regularidades da linguagem e as significações e as finalidades ( "purposes") expressas por meio do discurso" (HARRIS apud MAINGUENEAU; CHARAUDEAU, 2004, p. 44). Nas organizações, estas últimas são de extrema importância, pois são elas que estarão em consonância com as pretensões da empresa.

Para Orlandi (2002, p. 21), o discurso igualmente pode ser definido como "efeitos de sentido entre locutores", sabendo-se que esse "tem sua regularidade, tem seu funcionamento que é possível apreender se não opomos o social e o histórico, o sistema e a realização, o subjetivo ao objetivo, o processo ao produto" (ORLANDI, 2002, p. 22). Também pode ser entendido, referenciando o preconizado por Maingueneau (2002, p. 43), como sendo um modo de apreensão da linguagem, entendida como a atividade de sujeitos inscritos em contextos determinados, que, para efeitos deste trabalho, consiste no organizacional.

Outro termo dos estudos em $\mathrm{AD}$ que carece de delimitação conceitual é o ethos. Para tanto, utilizar-se-á a teoria desenvolvida por Maingueneau, defendendo que "Além da persuasão pelos argumentos [intrínsica a todo texto/comunicação gerada pela organização], a noção de ethos permite refletir sobre o processo mais geral da adesão dos sujeitos a uma certa posição discursiva" (MAINGUENEAU, 2005, p. 69). Aqui se dialoga com a construção intencional da imagem corporativa, a qual defendemos como análoga à elaboração do ethos organizacional.

Para abarcar os objetos de possíveis pesquisas com essa perspectiva, cabe falar em "cena", na qual os analistas do discurso, inspirados nas correntes pragmáticas, recorrem à metáfora teatral estóica, segundo a qual a sociedade seria um vasto teatro em que um papel seria atribuído a cada um dos atuantes, aqui, os stakeholders (MAINGUENEAU, 1997). Pode-se dizer, dessa forma, que a língua comporta todo um arsenal de relações inter-humanas, isto é, toda uma coleção de papéis que o sujeito pode escolher para si próprio, apresentando-se com base nesses como enunciador(es) comunicacional(is), e impor ao destinatário, bem como, "Utiliza-se, mais particularmente, a noção de 'cena' para a representação que um discurso faz de sua própria situação de enunciação" (MAINGUENEAU; CHARAUDEAU, 2004, p. 95). Ou seja, cena deve ser entendida, neste artigo, como as diversas situações vivenciadas nas/ pelas organizações.

$\mathrm{Na} \mathrm{AD}$, além do conceito de "papel", tem-se ainda o de "lugar", que visa enfatizar a preeminência e preexistência da topografia social sobre os falantes que aí venham a se inscrever. A especificidade desse "[...] repousa sobre o traço essencial segundo o qual cada um alcança sua identidade a partir e no interior de um sistema de lugares [...]" (MAINGUENEAU, 1997, p. 33). Na visão de Foucault (2002), o "lugar" termina por determinar qual é a posição que pode e deve ocupar cada indivíduo para dela ser sujeito enunciativo e poder verbalizar determinadas estruturas encontradas no discurso. Esse conceito de "lugar" é crucial a partir do instante em que se pensa nele em termos das formações discursivas (FD), as quais "determinam o que se pode e deve ser dito a partir de uma conjuntura dada" (MAINGUENEAU; CHARAUDEAU, 2004, p. 241). 
Assim, para Michel Foucault (1969 apud MAINGUENEAU, 1997, p. 14), uma FD é “[...] um conjunto de regras autônomas, históricas, sempre determinadas no tempo e no espaço que definiram em uma época dada, e para uma área social, econômica, geográfica ou lingüística [sic] dada, as condições de exercício da função enunciativa".

Partindo-se destes conceitos, sabe-se, igualmente que, quando passam de uma formação discursiva para outra, as palavras alteram o seu sentido, uma vez que, na visão de Ducrot (1987, p. 172), o sentido "[...] é uma representação da enunciação". Daí, poder-se falar em "efeito de sentido", que é a infinita variedade de valores dos quais se podem revestir os itens lexicais no discurso, em função do contextoda FD em que esses estejam inscritos. Dessa forma, pode-se afirmar que os efeitos de sentido nada mais são do que o resultado dos valores atribuídos pelo discurso ao significado previamente estabelecido na língua.

Orlandi (2002, p. 42-43) alerta:

[...] o sentido não existe em si, mas é determinado pelas posições ideológicas colocadas em jogo no processo sócio-histórico em que as palavras são produzidas. As palavras mudam de sentido segundo as posições daqueles que as empregam. Elas 'tiram' seu sentido dessas posições, isto é, em relação à formações ideológicas nas quais essas posições se inscrevem.

Isso pode ser observado com extrema clareza, por exemplo, quando um chefe fala algo a um subordinado, em que o chefe terá sempre mais força (de ordem) que um colega com o seu par, mesmo que esses usem a mesma estrutura linguística.

Igualmente, faz-se necessário abordar a problemática que envolve a embreagem. Esta estaria exposta nas marcas linguísticas por meio das quais se manifesta a enunciação, visto que os enunciados têm, como ponto de referência, o próprio ato de enunciar, do qual são produtos. Porém, só algumas das suas características são levadas em consideração, aquelas que são definidoras da situação de enunciação linguística, a saber: enunciadores e co-enunciadores, o momento e o lugar da enunciação. Esses três elementos formam a denominada embreagem textual à situação de enunciação, sendo apresentadas comumentes pelo "EU" e "TU" - embreagem de pessoa, marcada pela subjetividade enunciativa -, pelo "agora" - embreagem de tempo -, e pelo "aqui" - embreagem de espaço (ANDRADE, 2008, p. 72).

Com base no exposto, advoga-se, neste trabalho, que a identidade/imagem corporativa é construída via discurso (por meio dos “ingredientes" já apresentados), expresso nas comunicações dirigidas escritas pelas organizações.

Sabe-se que toda a comunicação dirigida escrita (CDE) tem uma função específica para o estabelecimento da comunicação numa empresa e deve possuir uma unidade de comando para facilitar o seu planejamento, execução e avaliação, que precisa estar em consonância com os objetivos e a imagem a ser construída acerca da organização, ainda porque a CDE só terá eficácia se estiver dentro de um planejamento global da comunicação, o qual deve existir na corporação. Dessa forma, cumprirá o seu papel de formadora de opinião pública, uma vez que, lembrando de novo, até a mais simples CDE construirá a imagem da organização junto aos seus diversos públicos. (ANDRADE, 2008, p. 31-32)

Estudar as CDEs como instrumentos elaborados em concordância com a identidade corporativa e dentro da FD da administração da organização, portanto, verbalizadoras dos discursos que vão alicerçar a imagem empresarial, é também um campo de amplo interesse de pesquisadores da área comunicacional voltada para o campo das empresas.

Uma observação [ainda] a fazer sobre este detalhe é que a comunicação pode existir de forma organizada ou desorganizada. No primeiro tipo, estão as organizações que valorizam a importância da comunicação como um todo e fazem uso da mesma de forma planejada. Já no segundo, infelizmente ainda a maioria das organizações brasileiras, temos duas situações: organizações que utilizam intuitivamente a comunicação sem planejamento; e organizações que pensam utilizar a comunicação de forma correta, baseando-se apenas no "achismo"; portanto, sem planejamento. (TAVARES, 2007, p. 13).

Este é um problema complicado e deve ser equacionado para que as empresas consigam perpertuar-se num mercado cada vez mais competitivo, em que os diferenciais são facilmente superados pelos concorrentes/competidores. Dessa forma, Bueno (2009) defende que a comunicação nas organizações precisa se impor como campo estratégico. Ampliar o 
número de estudos para que os profissionais também se qualifiquem e atualizem é um desafio a ser enfrentado pelos pesquisadores da área.

Salienta-se, por fim, Daniels, Spike e Papa (apud MARCONDES FILHO, 2009, p. 69), na proposta de três perspectivas de orientação das pesquisas científicas em Comunicação. Para efeitos deste estudo, a pesquisadora adotou a posição interpretativa para as investigações empreendidas no campo da comunicação organizacional, entendendo que "as organizações são culturas, que representam sistemas de signos e significados, oriundos de processos negociados e compartilhados".

\section{Um exemplo de possibilidade de pesquisa/análise ana área de Comunicação Organizacional}

\subsection{Uma CDE: uma peça publicitária do Banco do Brasil}

Neste trabalho, estuda-se uma peça publicitária $^{7}$ lançada pelo Banco do Brasil (BB) em 2011, que está disponível no site $<$ http://kmaweb.com.br/ blog-new $/ \mathrm{p}=5304>$ e teve como finalidade principal estreitar o relacionamento dessa instituição com o público jovem, transmitindo a imagem de um Banco igualmente jovem. Teve como texto o seguinte:

Ser independente é preferir um lugar ao sol em vez de sombra e água fresca.

Por isso, o BB criou um site para você expor suas ideias em um espaço todo seu.

eufacoacontecer.com.br

Onde TODA forma de independência vale a pena.

Onde SUA independência vale a pena.

\section{BANCO DA FLÁVIA}

Passa-se, a partir de agora, à análise propriamente dita do discurso organizacional expresso na peça em questão.

\subsection{Análise propriamente dita}

Para empreender esta análise, foi usada a Análise do Discurso, de linha francesa, teoria que é igualmente uma metodologia e que facilita a leitu-

\footnotetext{
${ }^{7}$ Peça disponível em: <http://kmaweb.com.br/blog-new/?p=5304>. Acesso em: 21 fev. 2013
}

ra de estudos focados nos discursos produzidos pela Comunicação Organizacional.

A peça publicitária, apresentada no item 3.1 e que servirá de exemplo para uma possível análise a ser empreendida, como já foi mencionado, foi lançada em 2011, na campanha publicitária do BB, sendo esta voltada ao segmento de clientes jovens a serem prospectados ou já pertencentes à clientela desse Banco.

Para empreender uma análise como a proposta, é necessário conhecer minimamente a organização e a sua atuação no mercado. Destacando-se que o Banco em questão é uma instituição centenária, sólida, mas que acompanha as demandas mercadológicas da atualidade, portanto, a força dos jovens como futuros clientes é reconhecida. Daí a necessidade de se construir um discurso/imagem voltado para juventude.

Feito isso, passa-se a observar a comunicação dirigida escrita (peça) em todos os aspectos de sua construção, pois, com base nesses, apreender-se-á a imagem corporativa da empresa em estudo.

Esta análise será iniciada por meio dos elementos do co-texto. Percebe-se que este é constituido por uma foto, na qual é apresentada uma jovem que retoma o novo posicionamento rejuvenescido que o próprio Banco quer passar para o mercado de si mesmo, ou seja, construiu-se o ethos organizacional embasado na própria imagem da peça. Esse ethos é o de ser humano independente que marca seu "lugar ao sol", fazendo apologia à ideia de se trabalhar em detrimento da "sombra e água fresca", que não conduz à independência financeira. Ethos esse igual ao do BB: instituição que marca o seu "lugar" na sociedade brasileira, fazendo um trabalho de qualidade, o qual garante a sua credibilidade, competência e solidez.

Observa-se que o enunciador (EU, quem elabora a peça), neste texto, sofre total apagamento em detrimento dos co-enunciadores (TU, para quem a peça foi pensada), explicitado nos pronomes "você", "suas", "seu" e "SUA". Até o "eu", expresso no endereço do site, refere-se igualmente a esse TU. Portanto, notou-se que há um apagamento dos embreantes de pessoa "EU" enunciativos. Isso ocorre de maneira proposital e se dá no intuito de conferir uma maior autenticidade à peça. $\mathrm{O}$ uso desse recurso é muito difundido em textos da área da comunicação social, bem como no meio científico, uma vez que isso proporciona às produções uma maior credibili- 
dade junto ao público receptor por parecer que foi realizado um relato independente de quem o apresenta, transparecendo, assim, um pseudodistanciamento em relação ao fato que está sendo apresentado. Também é um recurso de identificação do TU com o EU, conduzindo ao destaque do primeiro em relação ao segundo.

Sobre os embreantes de espaço (ou seja, as palavras ou expressões que ancoram a situação enunciativa em nível espacial), percebe-se que também foram apagados, fornecendo a impressão de um local destendido. Isso faz, na construção discursiva proposta, com que os leitores da peça tenham a sensação de que o BB está presente em todos os locais, o que é uma premissa identificatória do próprio Banco, que está presente em todo o território brasileiro.

Pensando nos embreantes de tempos, aquelas palavras ou expressões que ancoram a situação enunciativa em nível temporal, esse texto conta apenas com os tempos verbais para marcá-lo. Acerca destes, há os tempos verbais plenos - aqueles referentes ao modo indicativo (quadro 1)-, que foram produzidos no presente omnitemporal ou gnômico e no pretérito perfeito. O primeiro, de acordo com Fiorin (2002, p. 150-151), ocorre "quando o momento de referência é ilimitado e, portanto, também é o momento do acontecimento. É o presente utilizado para enunciar verdades eternas ou que se pretendem como tais". O segundo, por sua vez, "marca uma relação de anterioridade entre o momento do acontecimento e o momento de referencia presente" (p. 152).

Quadro 1 - Tempos Plenos - Sistema Enunciativo

\begin{tabular}{|c|c|c|}
\hline \multicolumn{2}{|c|}{ SISTEMA ENUNCIATIVO } \\
\hline Concomitância MR Presente & Linhas \\
\hline \multicolumn{2}{|c|}{ Presente omnitemporal } & é;faço; vale (2 vezes) \\
\hline Não-Concomitância & $\begin{array}{c}\text { Posterioridade } \\
\text { MA passada }\end{array}$ & Criou \\
\hline
\end{tabular}

Vale salientar também que foram colocados, no quadro 2, os semitempos que só expressam aspecto quando ligados aos tempos plenos que lhes determinam a situação comunicativa $(\mathrm{KOCH}, 2000$, p. 41-42). Com isso, igualmente, contribuem para a embreagem temporal do discurso, reforçando o mesmo resultado do quadro 1. Deve ser dito, ainda, que para representar essa situação peculiar foi usado o seguinte procedimento: a forma plena entre colchetes e, em destaque, o semitempo.

Quadro 2 - Semitempos - Sistema Enunciativo

\begin{tabular}{|c|c|c|}
\hline \multicolumn{2}{|c|}{ SISTEMA ENUNCIATIVO } \\
\hline Concomitância MR Presente & Linhas \\
\hline \multicolumn{2}{|c|}{ Presente omnitemporal } & $\begin{array}{c}\text { Ser [é]; [é] preferir; } \\
{[\text { faço] acontecer }}\end{array}$ \\
\hline Não-Concomitância & $\begin{array}{c}\text { Posterioridade } \\
\text { MA passada }\end{array}$ & {$[\mathrm{criou}]$ expor } \\
\hline
\end{tabular}

Feitas essas ponderações sobre a embreagem de tempo, pode-se concluir que, apesar da aparente objetividade existente na peça, há um "EU” representando a voz do Banco do Brasil não marcado no texto explicitamente, daí seu apagamento. Ou melhor, existe um comunicador que o representa em sua enunciação discusiva e assina a peça, que se dirige a um "TU" apontado como o público leitor dessa produção textual, a qual não mobiliza embreante de espaço algum de forma proposital, e as marcas de tempos presentes nos verbos (quadro 1 e 2).

Cabe destacar o lugar enunciativo ocupado pelo BB, pois este pode identificar seu discurso com o dos jovens, já que é uma instituição que se renova constantemente, utilizando a tecnologia virtual como uma das ferramentas mais eficazes da sua atuação frente a seus concorrentes, vide o próprio site adicionado para o estabelecimento de diálogo com o público receptor da peça.

Após a análise dos dados linguísticos, passa-se à das estratégias comunicativas utilizadas para a construção do sentido e do ethos.

Nota-se que, no primeiro enunciado ("Ser independente é preferir um lugar ao sol em vez de sombra e água fresca"), há uma tentativa comunicativa de se verbalizar uma lei feita, inclusive, com o uso do presente gnômico, que guia a conduta do BB e dos seus pretensos e atuais clientes: ambos - clientes e Banco - levam a sério a ideia de trabalhar para ter o seu dinheiro.

Há, igualmente, na peça publicitária estudada, a tentativa comunicativa de aproximar o leitor (futuro ou atual cliente jovem) de uma possibilidade de estabelecimento de sua independência atrelada aos valores inerentes ao Banco do Brasil.

Pode-se, ainda, afirmar que o que foi colocado nesta produção, foi feito para tornar os jovens clientes 
convictos da comunhão entre o pensamento/valores deles e o/os do BB, bem como convencê-los de que a independência dos stakeholders e o estabelecimento de diálogo entre eles e o Banco são uma constante para esta instituição do sistema bancário brasileiro.

Dessa forma, o BB construiu um discurso/um ethos organizacional favorável junto ao público-alvo em questão e, consequentemente, uma imagem corporativa "colada" com o esperado de um banco sólido no mercado, que já garantiu "o seu lugar ao sol", mas "antenado" e jovem na sua forma de pensar, que estabelece interação com esse público estratégico por meio de um canal igualmente atual e usado pela própria juventude, que é o site, acompanhando e utilizando, assim, uma mídia que está em alta na atualidade.

Nota-se, portanto, que depois dessa análise se verbalizou o que seria a imagem que o leitor da peça poderia depreender do próprio Banco do Brasil. Isso analisando apenas uma simples peça publicitária.

\section{Considerações finais}

Considera-se e advoga-se que pesquisar fontes e formas de se construir discursos que reforcem ou criem uma imagem corporativa forte no mercado é um dos grandes desafios atuais, bem como deve-se investigar aspectos significativos daqueles para áreas complementares, como é o caso da Comunicação e da Administração, investigações já pontuadas no corpo deste documento, centradas na Comunicação Organizacional.

Sabe-se que a unicidade discursiva, dentro e fora das organizações, reforça a identidade corporativa e produz uma imagem positiva das empresas junto aos seus stakeholders. Verbalizar algo que esteja em consonância com aquilo que a corporação quer passar para os seus públicos de interesse deve ser o direcionamento a ser seguido ao se elaborar qualquer comunicação dirigida. Isso transmite transparência identificatória empresarial e até seu posicionamento frente aos seus concorrentes no mercado em que atua, daí, inclusive, a importância de estudos como o proposto neste documento.

O objetivo deste trabalho foi atingido, pois o discurso do BB foi apreendido em sua construção e também se demonstrou de que forma auxilia na produção de uma imagem corporativa favorável e como se deve empreender uma pesquisa com esse tipo de objeto.

Cabe salientar que ainda há muito a ser pesquisado sobre esse tipo de discurso e que, quanto mais áreas lançarem luzes sobre isso (aqui entraram a teoria da Comunicação Organizacional e a da Análise do Discuro), melhor sustentado cientificamente o discurso ficará.

Neste artigo, também se demonstrou a possibilidade de estabelecer diálogos teóricos entre as duas áreas mencionadas, mas, para tanto, é preciso que isso se torne uma constante nos bancos universitários e nas propostas de pesquisa.

Por fim, cabe destacar um pensamento de Peter Drucker (apud PIMENTA, 2002, p. 53), que reflete também o defendido pela escritora deste trabalho: "Os administradores têm de aprender a conhecer a linguagem; a entender o que as palavras são e o que elas significam. Talvez, mais importante de tudo, eles têm de adquirir respeito pela linguagem como o nosso dom e herança mais importante". Pois, só assim o discurso organizacional será construído e embasado nessa linguagem e na identidade corporativa, bem como terá a força necessária para construir uma imagem organizacional positiva junto aos stakeholders empresariais.

\section{Referências}

ALMEIDA, Ana Luisa de Castro. Identidade, imagem e reputação organizacional: conceitos e dimensões da práxis. In: KUNSCH, Margarida M. Krohling (Org.). Comunicação organizacional: linguagem, gestão e perspectivas. v. 2. São Paulo: Saraiva, 2009, p. 31-52.

ANDRADE, Marta Cardoso de. Análise de textos da Comunicação empresarial. 2008. 302 f. Tese (Doutorado em Letras) - Instituto de Letras, Universidade Federal da Bahia, Salvador, 2008.

BUENO, Wilson da Costa. Comunicação empresarial: política e estratégica. São Paulo: Saraiva, 2009.

DUCROT, Oswald. O dizer e o dito. Rev. Tec. Trad. Eduardo Guimarães. Campinas, SP: Pontes, 1987.

FIORIN, José Luiz. As astúcias da enunciação: as categorias de pessoa, espaço e tempo. 2. ed.São Paulo: Ática, 2002.

FOUCAULT, Michel. A arqueologia do saber. Trad. Felipe Baeta Neves. 6. ed. Rio de Janeiro: Forense Universitária, 2002.

HALLIDAY, Tereza Lúcia. Discurso organizacional: uma abordagem retórica. In: KUNSCH, Margarida M. Krohling 
(Org.). Comunicação organizacional: linguagem, gestão e perspectivas. v. 2. São Paulo: Saraiva, 2009, p. 31-52.

JAPIASSU, H. O sonho transdisciplinar e as razões da filosofia. Rio de Janeiro: Imago, 2006.

KOCH, Ingedore Grunfeld Villaça. Argumentação e linguagem. 6. ed. São Paulo: Cortez, 2000.

LACOMBE, Francisco. Dicionário de negócios. São Paulo: Saraiva, 2009.

MAINGUENEAU, Dominique; CHARAUDEAU, Patrick. Dicionário de análise do discurso. Coord. Trad. Fabiana Komesu. São Paulo: Contexto, 2004.

MAINGUENEAU, Dominique. Ethos, cenografia, incorporação. In: AMOSSY, Ruth (Org.). Imagens de si no discurso: a construção do ethos. São Paulo: Contexto, 2005, p. 69-92.

MAINGUENEAU, Dominique. Termos-chave da análise do discurso. Trad. Márcio Venício Barbosa e Maria Emília Amarante Torres Lima. Belo Horizonte: UFMG, 2002.

MAINGUENEAU, Dominique. Novas tendências em análise do discurso. Trad. Freda Indursky. 3. ed. Campinas, SP: Pontes, 1997.

MARCONDES FILHO, Ciro (Org.). Dicionário da comunicação. São Paulo: Paulus, 2009.

ORLANDI, Eni Puccinelli. Análise do discurso: princípios e procedimentos. 4. ed. Campinas, SP: Pontes, 2002.

PIMENTA, Maria Alzira. Comunicação empresarial: conceitos e técnicas para administração. Campinas, SP: Alínea, 2002.

RABAÇA, Carlos Alberto; BARBOSA, Gustavo Guimarães. Dicionário de comunicação. São Paulo: Ática, 2001.

SIQUEIRA, Holgonsi Soares Gonçalves; PEREIRA, Maria Arleth. A interdisciplinaridade como superação da fragmentação. Disponível em: <http://www.angelfire.com/ sk/holgonsi/interdiscip3.html >. Acesso em: 21 fev. 2013.

TAVARES, Maurício. Comunicação empresarial e planos de comunicação: integrando teoria e prática. São Paulo: Atlas, 2007.

Recebido em: 23 de fevereiro de 2013 Aceito em: 08 de maio de 2013 